\title{
Required Interval of Weather Data for Proper Irrigation Scheduling
}

\author{
Samiha Ouda ${ }^{\#}$ and Ahmed Taha \\ Water Requirements and Field Irrigation Research Department, Soils, Water and \\ Environment Research Institute, Agricultural Research Center, Giza, Egypt.
}

\begin{abstract}
CLIMATE variability is very common in Egypt recently, therefore studying its effects on irrigation scheduling for crops is important. The objective of this study was to define a number of years of former weather data prerequisite to estimate evapotranspiration (ETo) to schedule irrigation in three sites in Egypt (El-Gharbia, Beni Swief and Sohag). Daily values of weather data were collected for 10 years (2008-2017).
\end{abstract}

Monthly ETo values were calculated by The BISm model. Descriptive statistics (mean, range, $\mathrm{R}^{2}, \mathrm{CV}$ and $\mathrm{SD}$ ) were done to determine the temporal and spatial variability between monthly values of weather elements, as well as ETo. Furthermore, assessment of ETo values trend (decreasing or increasing) was done.

The results showed that there were increasing temporal and spatial trends in the 10-year weather data, as well as ETo values in the 3 sites. However, it was more pronounced from 2015 to 2017. Furthermore, the results indicated that the range, CV\% and SD were lower in the 3-year interval (2015-2017), compared to 10-year interval for all sites. There were stronger relationships between weather elements and ETo values in the 3-year interval, compared to 10 year interval, as represented by $\mathrm{R}^{2}$ values.

Thus, it can be concluded that the recent 3-year interval is the most suitable interval for ETo calculation for proper irrigation scheduling to improve water management on field level in Egypt.

Keywords: Temporal variability, Spatial variability, BISm model, 10-year weather data, 3-year weather data.

\section{Introduction}

Weather data is the base for calculating evapotranspiration, irrigation scheduling and allocation of water between other sectors. Change in weather elements is caused by the expected climate change, which consequently will affect reference evapotranspiration (ETo) and irrigation water requirements for crops. Gardner et al. (1985) stated that ETo is a combination of two processes water evaporation from soil surface and transpiration from the growing plants. The latest research in Egypt by Ouda \& Noreldin (2017) reported that ETo values in the former 30 years exhibit an increasing trend. Many researchers reported the same increasing trends of ETo globally. ETo values were increasing in Taiwan as stated by Yu et al. (2002), when 48 years of weather data was used in the analysis. In
Northeast Brazil, Da Silva (2004) found that ETo values were increasing when 30 -year weather data were used. Burn \& Hesch (2007) reported an increasing trend of ETo in the northern regions of Canada. Similarly, Dinpashoh et al. (2011) stated that annual ETo values were increased by $28 \%$ in Iran during the period of 1965-2005.

The weather variables, which influence ETo are: Air temperature, sunshine duration (or solar radiation), relative humidity (or dew point temperature) and wind speed. Previous researches in Egypt dealt with the relation between weather elements and ETo. An analysis was conducted by Khail et al. (2011) between ETo and its components using 10-year averages of weather data from 1997-2006 in 20 sites in Egypt. They found that the values of correlation coefficient between ETo values and mean temperature was 0.63 , between

"Corresponding author email: samihaouda@yahoo.com 
ETo and sunshine duration, as well as relative humidity and wind speed were $0.72,0.76$ and 0.27 , respectively. Coefficient of determination $\left(\mathrm{R}^{2}\right)$ between ETo and temperature (maximum, minimum, mean and dew point) were $0.91,0.01$, 0.86 and 0.60 , respectively when 30 -year weather data from 1985-2014 (Noreldin et al., 2016) was used. Furthermore, they also stated that $\mathrm{R}^{2}$ values between solar radiation, and wind speed and ETo were 0.52 and 0.23 , respectively. Whereas, $\mathrm{R}^{2}$ values between dew point temperature and ETo was 0.60 . A 10-year weather data was used by Ouda \& Noreldin (2017) to calculate ETo in the Nile Delta and Valley. They also reported that $\mathrm{R}^{2}$ values between ETo and mean temperature were 0.79 and between ETo and dew point temperature were and 0.21 . Moreover, the value of $\mathrm{R}^{2}$ between ETo and solar radiation was 0.58 . It was 0.37 between ETo and wind speed. Although these investigations gave valuable findings, temporal and spatial variability analyses on weather elements and ETo data were not done before in Egypt.

The FAO Penman-Monteith method has been regarded as a worldwide standard method to estimate ETo (Allen et al., 1989; 1994 and 1998). Many researches, internationally and nationally, analyzed ETo values calculate by FAO Penman-Monteith method from the viewpoint of its spatial or temporal dispersal (McVicar et al., 2007; Buttafuoco et al., 2010; Song et al., 2010; Khail et al., 2011; Noreldin et al., 2016 and Ouda \& Noreldin, 2017). Furthermore, comparison between FAO Penman-Monteith and other equations calculating ETo was done (Maulé et al., 2006; Paltineanu et al., 1999; Sumner \& Jacobs, 2005 and Ouda et al., 2016). It was reported by Shahidian et al. (2012) that Penman-Monteith equation is the most consistent method calculating ETo in a widespread locations characterized by different climates as a result of its physical base and its consideration of the main climatic elements affecting evapotranspiration.

Irrigation is using most of water resources in Egypt. Because we are facing the problem of water scarcity, it is imperative to maximize the efficient use of irrigation water through controlling the application depths, thus, improving its management. In order to attain water needs of the cultivated crops, the calculation of ETo is an important tool (Shahidian et al., 2012), however availability of weather elements to calculate it stand as an impediment to attain it. To help agricultural extension workers to instruct farmers on the time and the amount of irrigation water application, information is needed on the number of years of weather data should they use to calculate ETo. Ouda \& Noreldin (2017) stated that ETo values became higher in the former 10-years interval from 2005 to 2014, compared to the average of former 20-year interval, as well as 30-year interval. Recently, there is a noticeable variability in weather elements, especially temperature as a result of the effect of climate change. Therefore, there is a need to determine how many years of past weather data that contains less variability and can be safely used to calculate ETo, and schedule irrigation. Thus, it could improve water management on farm level and could reduce irrigation water losses to ground water in Egypt.

The objective of this study was to define a number of years of former weather data prerequisite to estimate evapotranspiration (ETo) to schedule irrigation in three sites in Egypt.

\section{Materials and Methods}

\section{Description of the studied sites}

Three sites located in the Nile Delta and Valley were studied. These sites are: El-Gharbia to represent Nile Delta (latitude $=30.47^{\circ}$, longitude $=$ $32.14^{\circ}$ and elevation above the sea level $=14.80 \mathrm{~m}$ ), Beni Swief to represent Middle Egypt (latitude= $29.04^{\circ}$, longitude $=31.06^{\circ}$ and elevation above the sea level $=30.40 \mathrm{~m}$ ) and Sohag to represent Upper Egypt (latitude $=26.36^{\circ}$, longitude $=31.38^{\circ}$ and elevation above the sea level $=68.70 \mathrm{~m}$ ). These three sites are characterized by clay soil type and it is under surface irrigation. Figure 1 shows a map of the selected sites in the Nile Delta and Valley.

Daily weather elements for these sites were collected for 10 years (2008-2017) from the following website: https://power.larc.nasa.gov/ data-access-viewer. The recent 10 -year interval was selected because it reflected the recent variability existed in the weather pattern in Egypt as indicated by Ouda \& Noreldin (2017). The selected weather elements were maximum, minimum, and mean temperature (Tmean), dew point temperature (Td), as well as solar radiation (SRAD) and wind speed (WS). Monthly averages of each weather elements, as well as annual averages were calculated. 


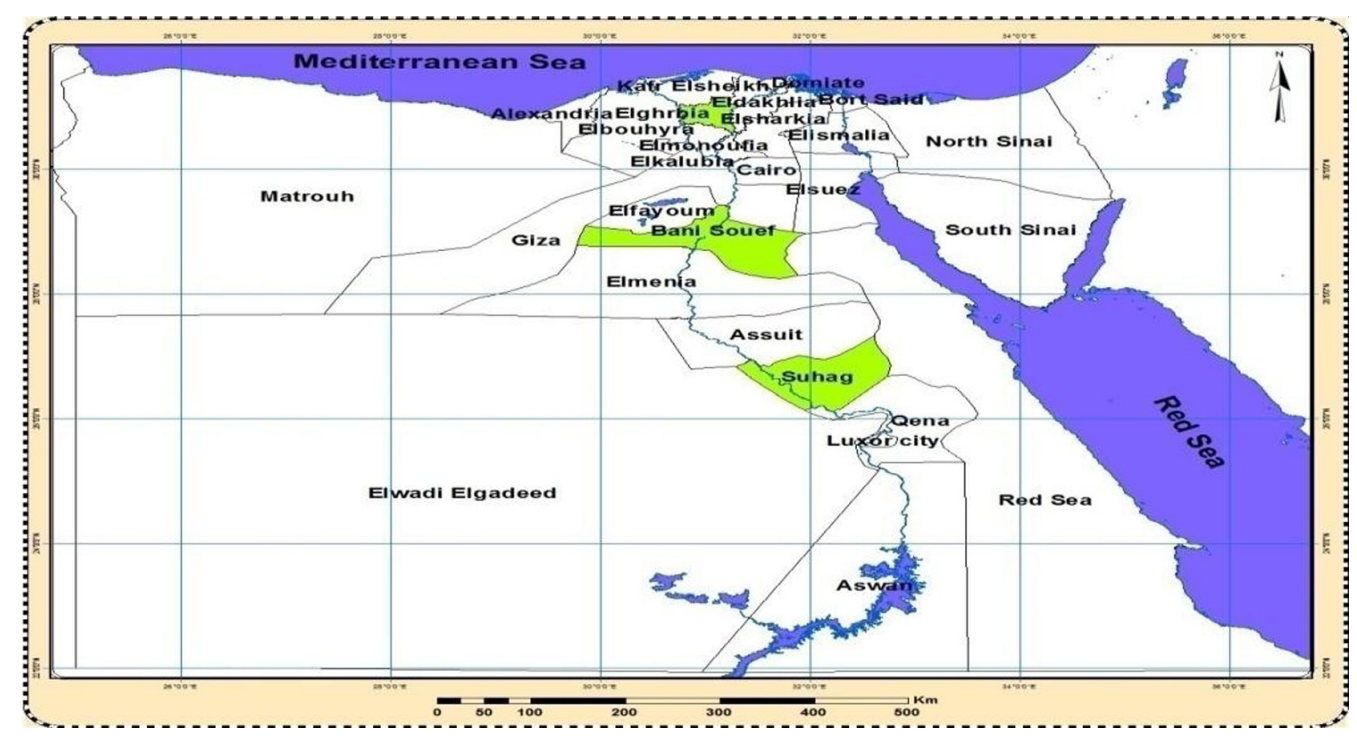

Fig. 1. Map of the selected sites in Egypt.

\section{Calculation of ETo}

The BISm model (Snyder et al., 2004) was used to calculate monthly ETo values in the three studied sites. The model was written using MS Excel to help people plan irrigation management of crops. The BISm model calculates ETo using the FAO Penman-Monteith equation (Monteith, 1965) as presented in the United Nations FAO Irrigation and Drainage Paper (FAO, 56) by Allen et al. (1998). Monthly averages of ETo values for the studied 10-year interval for the three sites were calculated.

\section{Statistical analysis}

The calculated annual weather elements and ETo values (2008-2017) were individually analyzed to study its temporal and spatial variability, as well as to check whether ETo values taking an decreasing or increasing trend. The temporal variability of ETo was determined using ETo averaged over 10-year intervals and the spatial variability of ETo was determined using ETo averaged over the three stations. Descriptive statistical analysis for the weather elements and ETo in these three sites were performed to calculate maximum and minimum values, the range between them and the mean (Sendicor, \& Cochran, 1980). Furthermore, coefficient of determination $\left(\mathrm{R}^{2}\right)$ between each weather element and ETo was calculated for the studied 10-year periods to test the strength of the relationship between them (Draper \& Smith, 1987). Standard deviation (SD) was calculated to quantify the amount of variation or dispersion within the values of each weather elements, as well as ETo values. Coefficient of variation (CV\%) was also calculated, which is defined as the ratio of the standard deviation to the mean (Sendicor \& Cochran, 1980).

The descriptive statistical analysis was used to determine how many years of past weather data that had less variability and can be used to calculate ETo and consequently schedule irrigation in three sites in Egypt.

\section{$\underline{\text { Results }}$}

Temporal and spatial variability of weather elements

Figure 2 indicated that there was low temporal variability in each site and high spatial variability between the three sites in solar radiation values. The highest values of solar radiation existed in Sohag and the lowest value existed in ElGharbia. The graph also showed that there was an increasing trend in El-Gharbia and Sohag in 2016 and 2017.

Regarding mean temperature, Fig. 3 indicated that there was high temporal variability in existed in each site, whereas there was low spatial variability in mean temperature existed between sites. Furthermore, in the three sites the highest value of mean temperature occurred in 2011, with highest value in Sohag site. It also showed from the figure that mean temperature is taking an increasing trend in 2016 and 2017. Dew point 
temperature followed the same trend as mean temperature in the three sites and within the studied years (Fig. 4), where there was high temporal variability in dew point temperature existed in each site. Whereas, there was low spatial variability in dew point temperature existed between sites. Furthermore, in the three sites the highest value of dew point temperature occurred in 2011, with highest value in Sohag site. It can also noticed from the figure that starting from 2015, the dew point temperature was taking an increasing trend.

Figure 5 indicted that there was high temporal variability in the wind speed existed in each site, whereas there was medium spatial variability in the wind speed existed between sites. Furthermore, in the three sites, the highest value of wind speed occurred in 2015 to 2017 and took an increasing trend.

Figure 6 indicated that the ETo values were fluctuating between 2008 and 2012, where the highest occurred in 2011 in all of the three sites. However, it took an increasing trend from 2015 to 2017. Furthermore, low temporal variability for ETo values existed between the three sites.

Based on the above results in the studied interval between 2008-2017, the highest values of each weather elements and ETo occurred in the year of 2011. Furthermore, an increasing trend was found starting from 2015 to 2017 . For that reason, another time interval was studied, namely a 3-year interval from 2015 to 2017 and it was statistically compared with the 10 -year time interval.

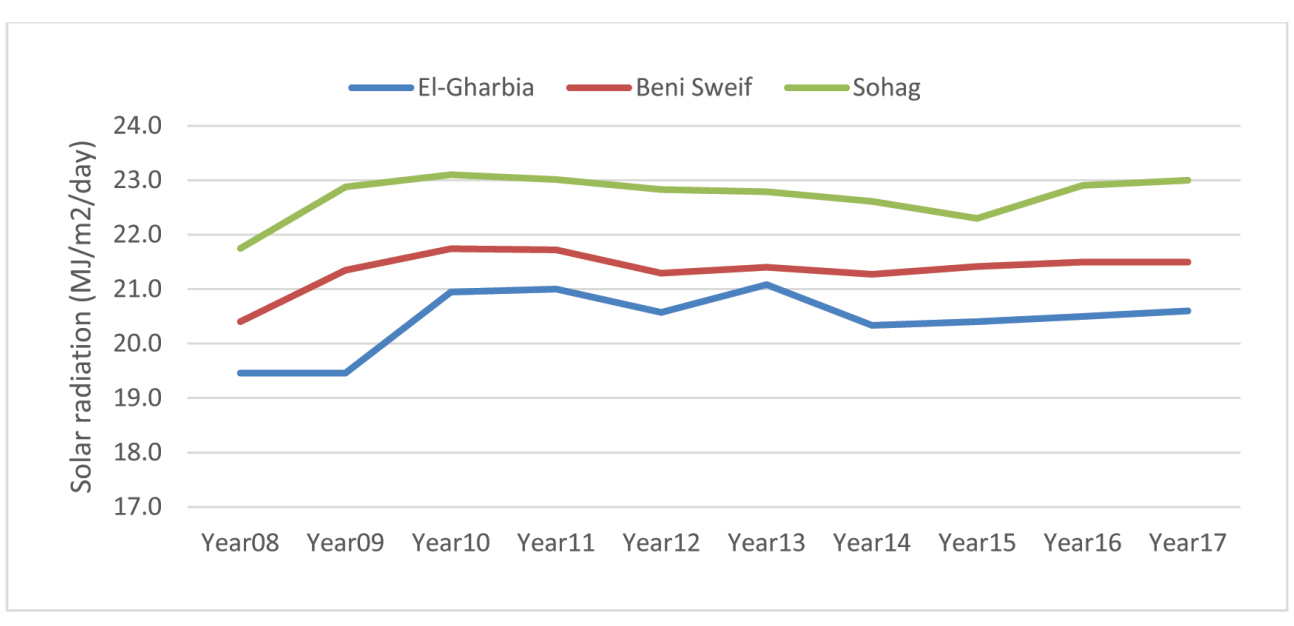

Fig. 2. Solar radiation spatial and temporal variability in 2008-2017.

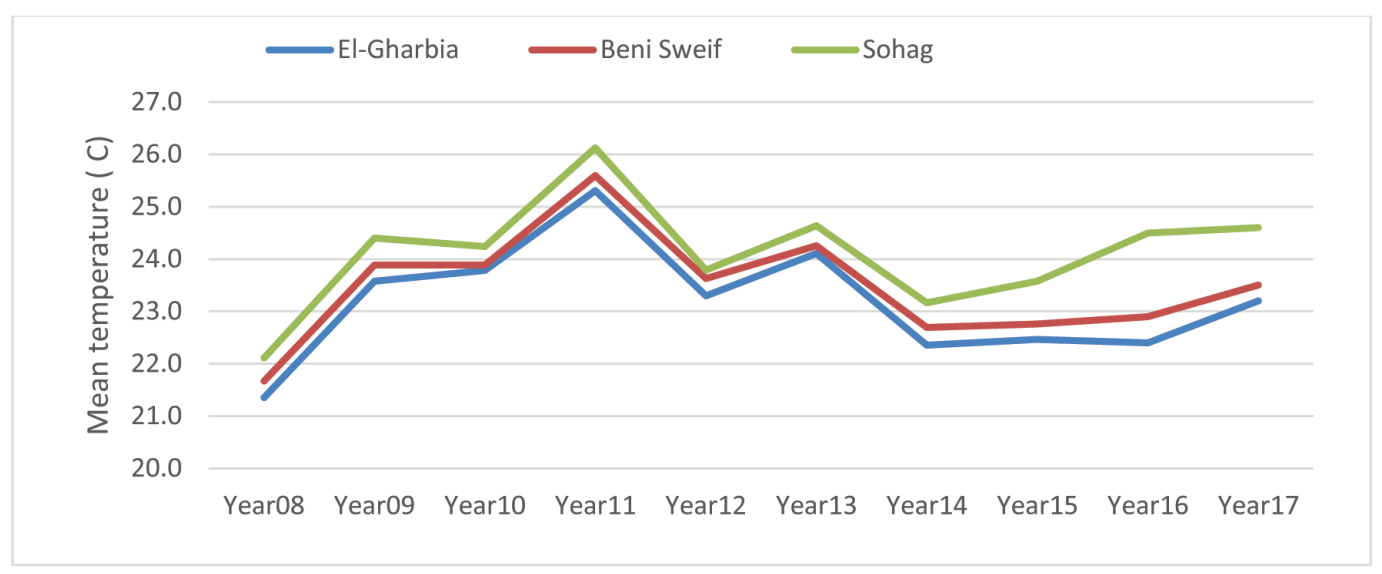

Fig. 3. Mean temperature spatial and temporal variability in 2008-2017. 


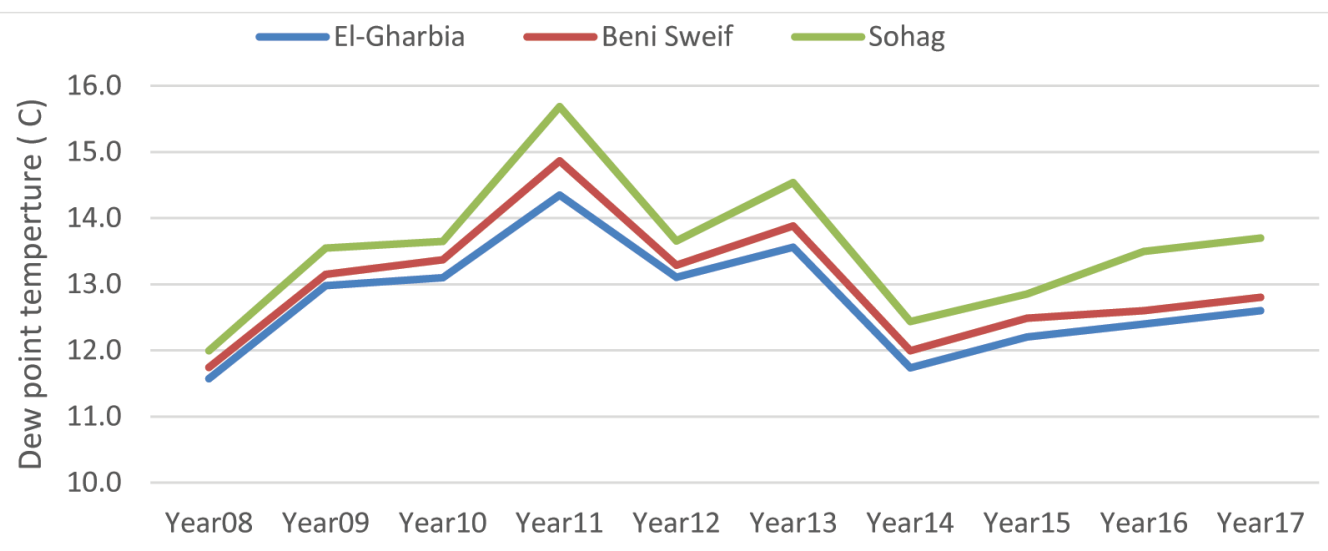

Fig. 4. Dew point temperature spatial and temporal variability in 2008-2017.

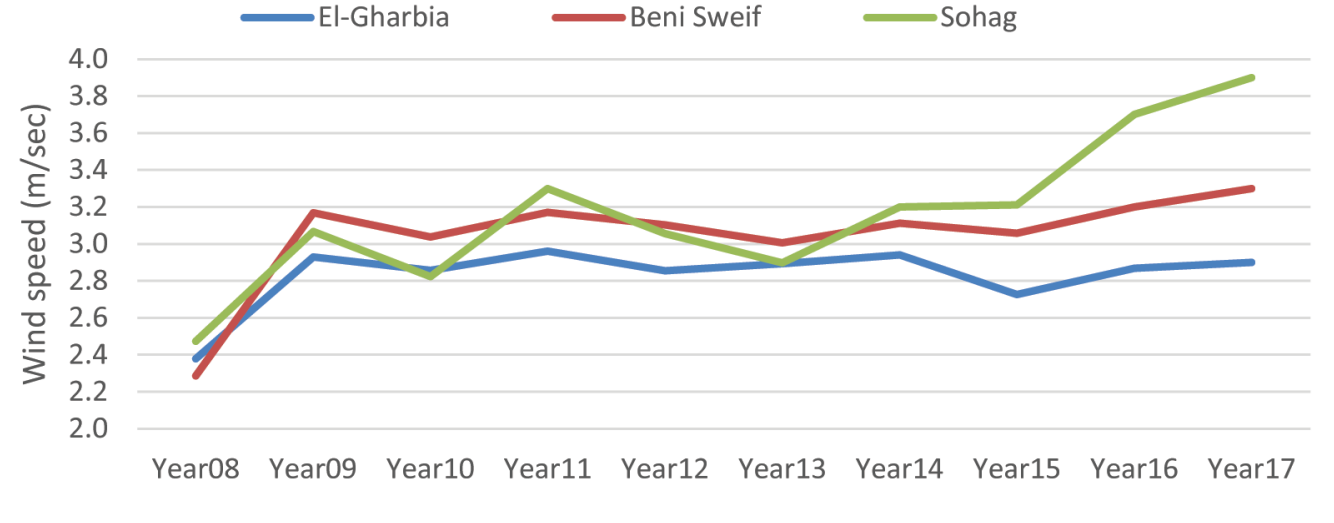

Fig. 5. Wind speed spatial and temporal variability in 2008-2017.

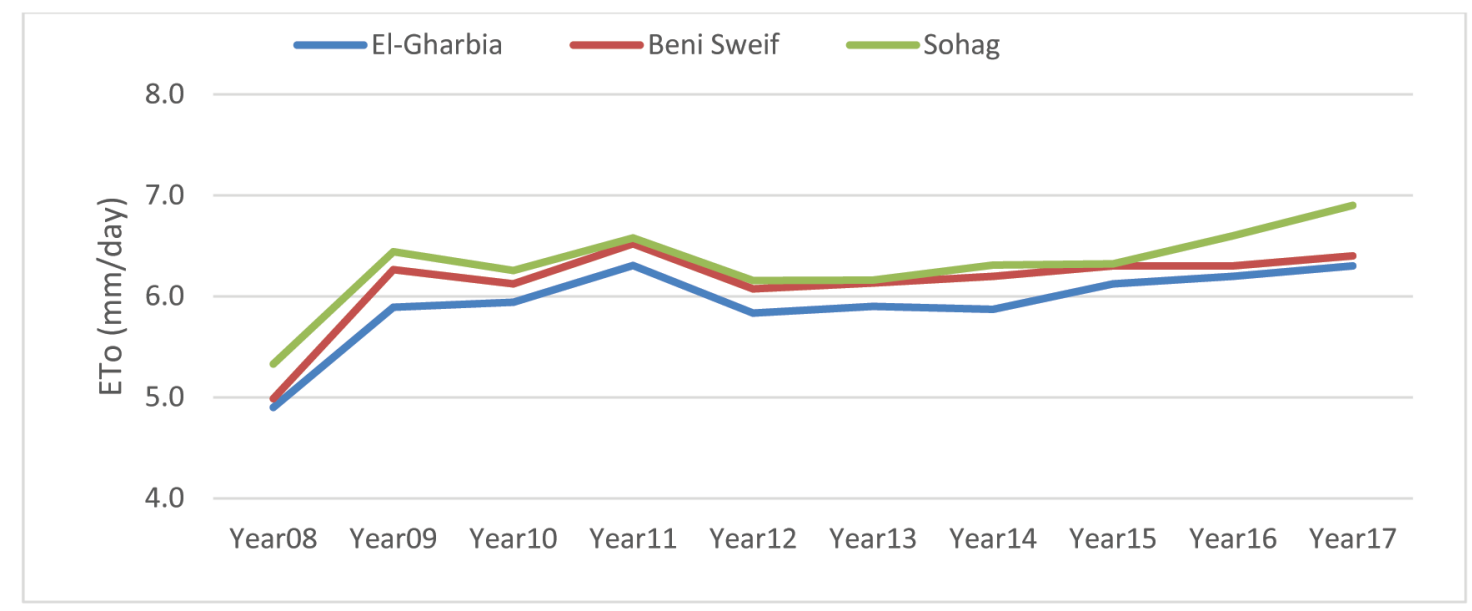

Fig. 6. ETo spatial and temporal variability in 2008-2017. 
Comparison between 10-year and 3-year intervals

Table 1 indicated that, in El-Gharbia site, the mean and maximum values of the 3-year interval were higher than its counterpart of 10year intervals for all weather elements, as well as ETo values. Furthermore, minimum values of 10year interval were lower than the values of 3-year interval. The results in Table 1 also revealed that the range, $\mathrm{CV} \%$, and $\mathrm{SD}$ values were lower in 3-year interval, compared to 10-year interval. $\mathrm{R}^{2}$ values were high, which implied stronger relationships between weather elements and ETo values in the 3-year interval, compared to 10 -year interval.

Regarding to Beni Sweif site, Table 2 showed that the mean value of the 3-year interval was higher than its counterpart of 10-year intervals for solar radiation, wind speed and ETo values. Moreover, minimum values of 3-year interval were higher for all weather, as well as ETo values, compared to 10 -year intervals values. Minimum values of 10-year interval were lower than the values of 3-year interval for mean temperature and wind speed. Similar to El-Gharbia site, the range, $\mathrm{CV} \%$ and $\mathrm{SD}$ values were lower in 3 -year interval, compared to 10 -year interval. Furthermore, there were stronger relationships between weather elements and ETo values in the 3-year interval, compared to 10-year interval, as represented by $\mathrm{R}^{2}$ values (Table 2). In Sohag site, the mean and minimum values of the 3 -year interval was lower than its counterpart of 10 -year intervals for all weather elements. Moreover, maximum values of 3-year interval were higher in all weather elements, as well as ETo, compared to 10-year interval for the rest of the elements. The same trend found in El-Gharbia and Beni Sweif sites was found for the range, $\mathrm{CV} \%$ and $\mathrm{SD}$ values, where it were lower in 3-year interval, compared to 10-year interval. Additionally, there were stronger relationships between weather elements and ETo values in the 3-year interval, compared to 10-year interval, as represented by $\mathrm{R}^{2}$ values (Table 3 ).

TABLE 1. Comparison between 10-year and 3-year intervals of weather elements and ETo values in El-Gharbia site.

\begin{tabular}{|c|c|c|c|c|c|c|c|c|c|c|}
\hline \multirow{2}{*}{ El-Gharbia } & \multicolumn{2}{|c|}{$\begin{array}{c}\text { SRAD } \\
\text { (MJ/m/day) }\end{array}$} & \multicolumn{2}{|c|}{$\begin{array}{l}\text { TMEAN } \\
\left({ }^{\circ} \mathbf{C}\right)\end{array}$} & \multicolumn{2}{|c|}{$\begin{array}{l}\text { Td } \\
\left({ }^{\circ} \mathbf{C}\right)\end{array}$} & \multicolumn{2}{|c|}{$\begin{array}{l}\mathrm{WS} \\
(\mathrm{m} / \mathrm{s})\end{array}$} & \multicolumn{2}{|c|}{$\begin{array}{c}\text { ETo } \\
\text { (mm/day) }\end{array}$} \\
\hline & 10-year & 3-year & 10-year & 3-year & 10-year & 3-year & 10-year & 3-year & 10-year & 3-year \\
\hline Mean & 20.4 & 20.5 & 23.2 & 22.7 & 12.8 & 12.4 & 2.8 & 2.8 & 5.9 & 6.2 \\
\hline Max value & 21.1 & 20.6 & 25.3 & 23.2 & 14.4 & 12.6 & 3.0 & 2.9 & 6.3 & 6.3 \\
\hline Min value & 19.5 & 20.4 & 21.4 & 22.4 & 11.6 & 12.2 & 2.4 & 2.7 & 4.9 & 6.1 \\
\hline Range & 1.6 & 0.2 & 4.0 & 0.80 & 2.8 & 0.40 & 0.6 & 0.2 & 1.4 & 0.18 \\
\hline CV\% & 2.8 & 0.5 & 4.8 & 2.0 & 6.6 & 1.6 & 6.1 & 3.3 & 6.8 & 1.4 \\
\hline SD & 0.6 & 0.1 & 1.1 & 0.4 & 0.8 & 0.2 & 0.2 & 0.1 & 0.4 & 0.1 \\
\hline $\mathrm{R}^{2}$ & 0.39 & $0.99 * *$ & 0.34 & $0.75^{*}$ & 0.26 & $0.99 * *$ & $0.69^{*}$ & $0.83 *$ & 1.00 & 1.00 \\
\hline
\end{tabular}

TABLE 2. Comparison between 10-year and 3-year intervals of weather elements and ETo values in Beni Sweif site.

\begin{tabular}{|c|c|c|c|c|c|c|c|c|c|c|}
\hline \multirow{2}{*}{ Beni Swief } & \multicolumn{2}{|c|}{$\begin{array}{c}\text { SRAD } \\
\text { (MJ/m/day) }\end{array}$} & \multicolumn{2}{|c|}{$\begin{array}{l}\text { TMEAN } \\
\left({ }^{\circ} \mathbf{C}\right)\end{array}$} & \multicolumn{2}{|c|}{$\begin{array}{l}\text { Td } \\
\left({ }^{\circ} \mathrm{C}\right)\end{array}$} & \multicolumn{2}{|c|}{$\begin{array}{l}\text { WS } \\
(\mathbf{m} / \mathbf{s})\end{array}$} & \multicolumn{2}{|c|}{$\begin{array}{c}\text { ETo } \\
\text { (mm/day) }\end{array}$} \\
\hline & 10-year & 3-year & 10 -year & 3-year & 10 -year & 3-year & 10-year & 3-year & 10-year & 3-year \\
\hline Mean & 21.4 & 21.5 & 23.5 & 23.1 & 13.0 & 12.6 & 3.0 & 3.2 & 6.1 & 6.3 \\
\hline Max value & 21.7 & 21.5 & 25.6 & 23.5 & 14.9 & 12.8 & 3.3 & 3.3 & 6.5 & 6.4 \\
\hline Min value & 20.4 & 21.4 & 21.7 & 22.8 & 11.7 & 12.5 & 2.3 & 3.1 & 5.0 & 6.3 \\
\hline Range & 1.3 & 0.08 & 3.9 & 0.7 & 3.1 & 0.3 & 1.0 & 0.2 & 1.5 & 0.1 \\
\hline CV\% & 1.7 & 0.2 & 4.5 & 1.7 & 7.0 & 1.2 & 9.2 & 3.8 & 6.9 & 0.9 \\
\hline SD & 0.4 & 0.05 & 1.1 & 0.4 & 0.9 & 0.2 & 0.3 & 0.1 & 0.4 & 0.1 \\
\hline $\mathrm{R}^{2}$ & $0.84 *$ & $0.90 *$ & 0.43 & $0.99 * *$ & 0.29 & $0.90 *$ & 0.63 & $0.70 *$ & -- & -- \\
\hline
\end{tabular}

*and ** indicate significant at 0.01 and 0.05 level of significance. 
TABLE 3. Comparison between 10-year and 3-year intervals of weather elements and ETo values in Sohag site.

\begin{tabular}{|c|c|c|c|c|c|c|c|c|c|c|}
\hline \multirow[t]{2}{*}{ Sohag } & \multicolumn{2}{|c|}{$\begin{array}{c}\text { SRAD } \\
\text { (MJ/m/day) }\end{array}$} & \multicolumn{2}{|c|}{$\begin{array}{c}\text { TMEAN } \\
\left({ }^{\circ} \mathbf{C}\right)\end{array}$} & \multicolumn{2}{|c|}{$\begin{array}{c}\text { Td } \\
\left({ }^{\circ} \mathbf{C}\right)\end{array}$} & \multicolumn{2}{|c|}{$\begin{array}{l}\text { WS } \\
(\mathbf{m} / \mathbf{s})\end{array}$} & \multicolumn{2}{|c|}{$\begin{array}{c}\text { ETo } \\
\text { (mm/day) }\end{array}$} \\
\hline & 10-year & 3-year & 10-year & 3-year & 10-year & 3-year & 10-year & 3-year & 10-year & 3-year \\
\hline Mean & 23.0 & 22.7 & 24.6 & 24.2 & 13.7 & 13.4 & 3.9 & 3.6 & 6.3 & 6.3 \\
\hline Max value & 22.3 & 23.0 & 23.6 & 24.6 & 12.9 & 13.7 & 3.2 & 3.9 & 6.2 & 6.3 \\
\hline Min value & 22.7 & 22.3 & 24.2 & 23.6 & 13.4 & 12.9 & 3.6 & 3.2 & 6.3 & 6.2 \\
\hline Range & 1.4 & 0.70 & 4.0 & 1.02 & 3.7 & 0.84 & 1.4 & 0.69 & 1.6 & 0.16 \\
\hline CV\% & 1.8 & 1.7 & 4.4 & 2.3 & 7.7 & 3.3 & 13.1 & 9.8 & 6.5 & 1.4 \\
\hline SD & 0.4 & 0.38 & 1.1 & 0.56 & 1.0 & 0.44 & 0.4 & 0.35 & 0.4 & 0.09 \\
\hline $\mathrm{R}^{2}$ & 0.64 & $0.98 * *$ & 0.54 & $0.97 * *$ & 0.27 & $0.98 * *$ & 0.79 & $0.96^{* *}$ & -- & -- \\
\hline
\end{tabular}

\section{Discussion}

Weather elements that have important influence in reference evapotranspiration are air temperature solar radiation, wind speed, and dew point temperature. Our results showed increasing temporal and spatial trends in the studied solar radiation, mean temperature, dew point temperature and wind speed values in the 10-year interval and 3 sites. The highest values of these were found in 2011 in the three sites. Furthermore, the lowest values were found in El-Gharbia and the highest values were found in Sohag sites. These results are supported with the findings of Khailet al. (2011), Noreldin et al. (2016) and Ouda \& Noreldin (2017).

Furthermore, Sohag site is located on higher latitude, i.e., $26.36^{\circ}$, whereas El-Gharbia is located on lower latitude, i.e., $30.47^{\circ}$, which explained the highest values of solar radiation and air temperature in Sohag site. Trenberth et al. (2009) indicated that latitude is the main factor affecting the received total energy. In Egypt, the apparent position of sun affecting solar radiation, where solar radiation is gradually decreases from south (maximum value) to north (lower value) (Morsy et al., 2016). They also added that the maximum core of wind speed is found over south of Egypt, where Sohag is located. In addition, they stated that minimum core of wind is found over Middle Egypt in all seasons, where Beni Sweif site is located.

Allen etal.(1998) stated that "ETo expresses the evaporating power of the atmosphere at a specific location and time of the year." Furthermore, Labedzki et al. (2011) reported that "ETo values measured or calculated at different locations or in different seasons are comparable as they refer to the evapotranspiration from the same reference surface." Our results indicated that, as result of increasing temporal and spatial variability in the studied weather elements, ETo values was the lowest in El-Gharbia site and the highest in Sohag site. Furthermore, the highest value was found in 2011 in the three sites. Labedzki et al. (2011) reported that fluctuations in solar radiation and temperature were found to have large magnitudes on ETo and that can explain the high value of ETo in Sohag, compared to the other two sites. Our results implied that climate is getting warmer and it is more noticeable in small temporal scale, namely 3-year interval than large scale, namely 10-year interval. Soltani \& Soltani (2008) related the increasing trends in air temperature to the observed global warming, as a result of increased concentrations of anthropogenic greenhouse gases.

Our analysis indicated that most of weather elements and ETo value exhibit low temporal variability in the recent 3-year interval from 20152017. This result is supported with the findings of Ouda et al. (2018). Furthermore, the comparison between the values of 10-year interval weather data, as well as ETo values (2008-2017) and its counterpart values of 3-year interval (2015-2017) in the three sites showed different spatial trends. The range, $\mathrm{CV} \%$ and $\mathrm{SD}$ values were lower in 3 -year interval in the three sites, which implied that the temporal variation between the two intervals was low. Our results also indicated higher $\mathrm{R}^{2}$ value between weather elements and ETo in 3-year interval, compared to its counterpart value in 10- year interval. This result reflects stronger relationship between weather elements and ETo in 3-year interval. Similar results were obtained in Egypt by Khail et al. (2011) and Ouda \& Noreldin (2017) using the 10-year interval of weather data 
and for 17 sites. Similarly, Labedzki et al. (2011) stated that, in Poland, ETo is highly sensitive to temperature, followed by solar radiation, followed by vapor pressure deficit, as well as wind speed.

\section{Conclusion}

The simple methodology applied in this paper could be used by extension workers in developing countries to better manage irrigation water on farm level. The above analysis showed that the temporal variability of weather elements in the 3-year interval (2015-2017) is lower than its counterpart in the 10-year interval (2008-2017) in the three selected sites. Thus, it can be concluded that the recent 3 -year interval is the most suitable interval for ETo calculation in the selected sites and for irrigation scheduling to improve water management on field level in Egypt. In addition, this methodology could be applied in the near future under expected weather variability and a new time-interval could be developed.

\section{$\underline{\text { References }}$}

Allen, R.G., Jensen, M.E., Wright, J.L. and Burmn, R.D. (1989) Operational estimate of reference evapotranspiration. Agron. J. 81, 650-662.

Allen, R.G., Smith, M., Perrier, A. and Pereira, L.S. (1994) An update for the definition of reference evapotranspiration. ICID Bull. 43, 1.

Allen, R.G., Pereira, L.S., Raes, D. and Smith, M. (1998) Crop evapotranspiration - guidelines for computing crop water requirements. FAO Irrigation and Drainage. Paper No. 56. FAO, Rome. pp. 300.

Burn, D.H. and Hesch, N.M. (2007) Trends in evaporation for the Canadian Prairies. J. Hydrol. 336, 61-73.

Buttafuoco, G., Caloiero, T. and Coscarelllr, R. (2010) Spatial uncertainty assessment in modelling reference evapotranspiration at regional scale. Hydrol. Earth Syst. Sci. Discuss. 7, 4567, 2010. DOI:105194/hessd-7-4567.

Da Silva, V.P.R. (2004) On climate variability in Northeast of Brazil. J. Arid Environ. 58, 575-596.

Dinpashoh, Y., Jhajharia, D., Fakheri-Fard, A., Singh, V.P. and Kahya, E. (2011) Trends in reference crop evapotranspiration over Iran. J. Hydrol. 399, 422433.
Draper, N.R. and Smith, H. (1987) "Applied Regression Analysis", pp. 397-402. John Willy and Sons, Inc. New York.

Gardner, F.P., Pearce, R.B. and Mitchell, R.L. (1985) "Physiology of Crop Plants". Iowa State University Press, Ames. USA.

Khail, F.A., Ouda, S.A., Osman, N. and Khamis, E. (2011) Determination of agro-climatic zones in Egypt using a robust statistical procedure. Proceedings of the $15^{\text {th }}$ International Conference on Water Technology, Alexandria, Egypt, $30^{\text {th }}$ May-2 ${ }^{\text {nd }}$ June.

Labedzki, L., Kanecka-Geszke, E., Bak, B. and Slowinska, S. (2011) "Estimation of Reference Evapotranspiration using the FAO PenmanMonteith Method for Climatic Conditions of Poland, Evapotranspiration", Leszek Labedzki (Ed.), ISBN: 978-953-307-251-7, InTech, Available from: http:// www.intechopen.com/books/evapotranspiration/ estimation-of-reference-evapotranspiration-usingthefao-penman-monteith-method-for-climaticconditin

Maulé, C., Helgalson, McGinn, S.W. and Cutforth, H. (2006) Estimation of standardized reference evapotranspiration on the Canadian Prairies using simple models with limited weather data. Canadian Biosystems Engineering, 48(1), 1.11.

McVicar, T.R., Van Niel, T.G., Hutchinson, L.L., Mu, X. and Liu, Z. (2007) Spatially distributing monthly reference evapotranspiration and pan evaporation considering topographic influences. J. Hydrol. 338, 196.

Monteith, J.L. (1965) Evaporation and environment, in: The state and movement of water in living organisms, Symposium Society Experimental Biology, Fogg, G.E. (Ed.), 19, pp. 205-234, Cambridge University Press, London.

Morsy, M.T., Sayad, A. and Ouda, S.A. (2016) Potential evapotranspiration under present and future climate. In: "Management of Climate Induced Drought and Water Scarcity in Egypt: Unconventional Solutions". Springer Publishing House.

Noreldin, L.T., Ouda, S.A. and Amer, A. (2016) Agroclimatic zoning in the Nile Delta and Valley of Egypt to improve irrigation water management. Journal of Land and Water Development. 31(X-XII), 113-117. 
Ouda, S. and Noreldin, T. (2017) Evapotranspiration data to determine agro-climatic zones in Egypt. Journal of Water and Land Development, 32(I-III), 79-86.

Ouda, S.A., Noreldin, T. and Hosny, M. (2016) Evapotranspiration under changing climate. In: "Major Crops and Water Scarcity in Egypt", pp 1-22. Springer Publishing House. ISBN: 978-3319-21770-3.

Ouda, S., Zohry, A. and Noreldin, T. (2018) Irrigation scheduling to maximize water productivity of the crop rotation. In: "Crop Rotation: An approach to Secure Future Food". Springer Publishing House. ISBN 978-3-030-05350-5.

Paltineanu, C., Panoras, A.G., Mavroudis, I.G. and Louisakis, A. (1999) Estimating reference evapotranspiration and irrigation water requirements in the Gallikos river basin, Greece. International Agroghisics, 13, 49-62.

Sendicor, G.W. and Cochran, W.G. (1980) "Statistical Method", $7^{\text {th }}$ ed. Iowa State University Press. Ames, Iowa, USA.

Shahidian, S.R., Serralheiro, J., Serrano, J., Teixeira, N.H. and Francisco, S. (2012) "Hargreaves and Other Reduced-Set Methods for Calculating Evapotranspiration, Evapotranspiration - Remote Sensing and Modeling", Ayse Irmak (Ed.), ISBN: 978-953-307-808-3, In. Tech, Available from:http:// www.intechopen.com/books/evapotranspirationremote-sensing-and-modeling/hargreaves- and-otherreduced-set-methods-for-calculatingevapotranspiration.

Sumner, D.M. and Jacobs, J.M. (2005) Utility of Penman-Monteith, Priestley-Taylor, reference evapotranspiration and pan evaporation methods to estimate pasture evapotranspiration. J. Hydrol. 308, 81 .

Snyder, R.L., Orang, M., Bali, K. and Eching, S. (2004) Basic irrigation scheduling (BIS). http://www. waterplan.water.ca.gov/landwateruse/wateruse/Ag/ CUP/Californi/Climate_Data_010804.xls.

Song, W., Zhang, H.L., Snydre, R.L., Anderson, F.E. and Chen, F. (2010) Distribution and trends in reference evapotranspiration in the North China plain. J. Irrig. Drain. E.-ASCE. 136, 240.

Soltani, E. and Soltani, A. (2008) Climatic change of Khorasan, North-East of Iran, during 1950-2004. Res. J. Environ. Sci. 2(5), 316-322.

Trenberth, K.E., Fasullo, J.T. and Kiehl, J. (2009) Earth's global energy budget. Bulletin of the American Meteorological Society, 90, 311-324.

Yu, P.S., Yang, T.C. and Chou, C.C. (2002) Effects of climate change on evapotranspiration from paddy fields in southern Taiwan. Clim Change, 54, 165 179.

(Received 18/10/2018;

accepted 20/ 1/2019) 


\section{الفتره الزمنيه المطلوبه من بيانات الطقس لعمل جدولة مناسبة للري \\ سميحه عوده و أحمد طه \\ قسم بحوث المقننات المائية و الرى الحقلى ـ معهز بحوث الأر اضى والمياه و البيئة ـ مركز البحوث

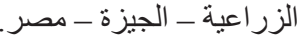

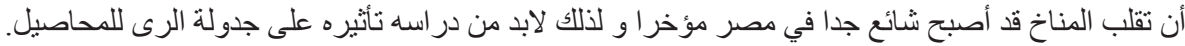

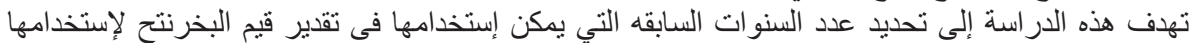

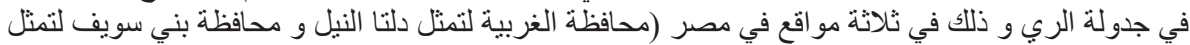

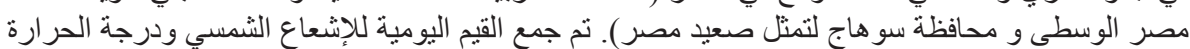

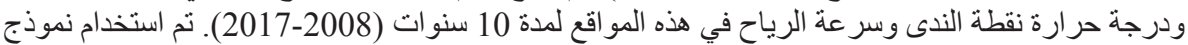

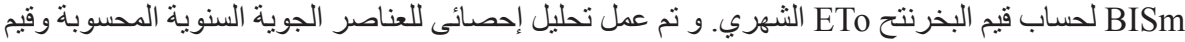

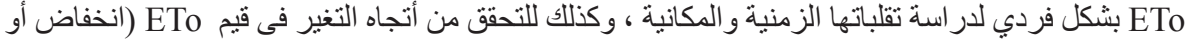

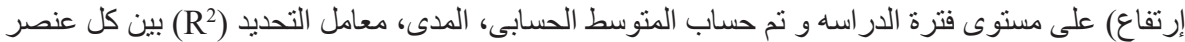

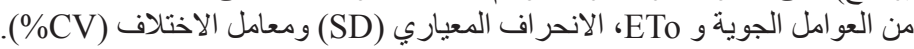

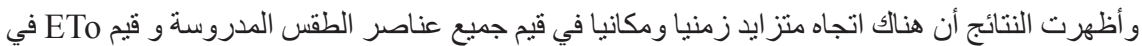

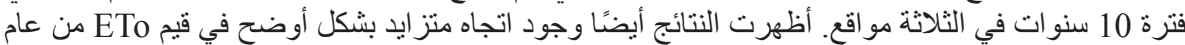

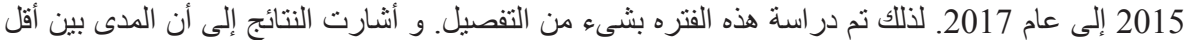

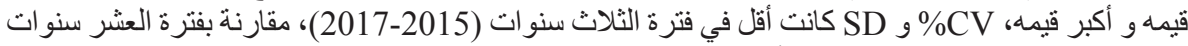

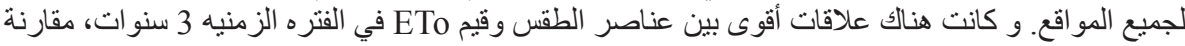

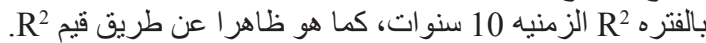

و على ذللك ، يمكن الأستنتاج أن الثثلاثة سنو ات الأخيرة (2015-2017) هي الفترة الأكثر ملاءمة لحساب ETo لعمل جدولة للري لتحسين إدارة المباه على المستوى الحقلى في مصر. 